\title{
Uneven Opening of China's Society, Economy, and Politics: Pro-Growth Authoritarian Governance and Protests in China
}

This is a final draft submitted to the journal prior the proof version. It was eventually published in Journal of Contemporary China, 2010, Vol. 19 (67): 819-835.

Hongyi Lai, University of Nottingham

\begin{abstract}
The model of China's development has attracted worldwide and indeed China has undergone great transformation in the reform era. This article evaluates China's model of development especially the main defining component, i.e., China's model of governance. It suggests that China's model of development is marked by an imbalance between fast opening of the economy and the society and sluggish opening of the political system. The Chinese society has become much more open, reflected in the Chinese growing awareness of their legal rights. The Chinese economy has become highly internationalized and open. But much of Chinese politics is closed. China's governance, a major component of China's model of development, can be regarded as pro-growth authoritarianism. The Chinese state is effective in opening up the economy, promoting reform, and generating economic growth. Nevertheless, the Chinese state offers weak protection of people's rights and ineffectual mitigation of social grievances. These imbalances help produce social protests. A viable solution requires faster opening of the political process and greater respects for interests of the society and its members.
\end{abstract}




\section{Introduction: Uneven Opening of the Society, Economy, and Politics in China}

In the reform era China has undergone tremendous transformation and opening. The glowing success of the Beijing Olympic Games, including the mega media show of the opening ceremony, the smooth completion of the games, and fantastic sports ventures, allows China to showcase its economic success.

Nevertheless, the transformation in China has been uneven across spheres. China's society has also been opened up significantly. The Chinese are no longer ignorant about the outside world. They are attentive to the popular culture, especially movies, TV programs, music, entertainment, dresses, and life style of the West. More importantly, the Chinese have become accustomed to individual initiatives, such as economic entrepreneurship and volunteering for the Olympic Games. Importantly, they are aware of their legal rights and keen to defend them. This marks a sharp departure from their docile or passive submission to the state in the pre-reform period. In the economic realm, China's opening has been most impressive. After three decades of reform China has been transformed from one of the most isolated economies in the world into one of the most open in the developing world.

However, in the political realm, despite overhaul of the governmental structure, agencies, and work style, the state has not been changed dramatically. The Chinese Communist Party still dominates politics, and the policy making process remains largely inaccessible to the public. As a result, the state and officials often ignore people's rights, legitimate interests, due process and relevant laws. Therefore, ironically, in the recent two decades frequent collective protests have gone hand in hand with high economic growth. ${ }^{1}$

The purpose of this article is to analyze the features and limits of the mode of development, especially the model of governance in China. China's model of development is marked by uneven economic-social and political opening of China. China's model of governance can be characterized by pro-growth authoritarianism. I suggest that the Chinese model of governance is characterized by a gap between fast economic and social opening and slow political opening. As far as governance is concerned, the Chinese state is indeed very effective in opening up and modernizing the economy. However, it is very ineffective when it comes to protecting and respecting citizens' legitimate social and economic rights, controlling rampant corruption, and enforcing the rule of law. As Gilley put dramatically, "China's performance in rights and freedom (author's note: predominantly political freedom) is much worse than most developing countries, excepting those where political disorder cancels out any formal freedoms". 2 High growth is thus not necessarily followed by a decrease in social protests. On the contrary, flagrant violation of citizens' rights in official aggressive pursuit of high growth results in public outrages and protests.

\footnotetext{
${ }^{1}$ For discussion of protests and instability in China, refer to David Shambaugh, ed. Is China Unstable? Armonk, New York: M.E. Sharpe, 2000, Steven F. Jackson, "Introduction: A Typology for Stability and Instability in China," pp. 3-15. For a recent discussion, see Susan Shirk, China: Fragile Superpower. Oxford and New York: Oxford University Press, 2007.

${ }^{2}$ Bruce Gilley, 2005. "Two Passages to Modernity," in Edward Friedman and Bruce Gilley, eds. Asia's

Giants: Comparing China and India (New York and Houndmills, Palgrave Macmillan), 20.
} 
This article will first discuss the opening of the society in China. It will then examine the rapid opening of the Chinese economy and the positive aspects of governance in China. This is followed by a discussion of slow political opening and the severe limits of governance in China, as well as of the consequences of uneven opening, i.e., frequent protests in the wake of high economic growth and in China. The article concludes by summing up the findings of the article and emphasizing the need for greater political opening in China.

\section{Social Opening and Rights Consciousness}

In the reform era the former and onerous restrictions on the society have been lifted or eroded. People are freer to migrate across counties and provinces and even outside China; they no longer need state's approval in finding a job and getting married; they are free to engage and even indulge in a variety of entertainment and hobbies and choose their favorite fashions.

Associated with economic opening is social opening. In the 1980s the state dismantled collective farming and reformed state-owned enterprises. As a result, collectivism declined. Individual economic initiatives are promoted and rewarded, reflected in the state's encouragement of private enterprises and rise of private entrepreneurs which were prohibited during late Mao's era. The Chinese are more interested in personal and family material well-being than they did in Mao's era.

The Chinese become more conscious of their legal rights (especially economic and social rights). A small sample survey of Chinese from various professions from 2005 to 2006 suggested that over 60 percent of the urban Chinese and 38 percent of rural Chinese were aware that the Constitution protected citizens' legal private property and that 90 percent of the urban Chinese and over 60 percent of peasants believed correctly that the Constitution served to regulate state power and protect citizens' rights. ${ }^{3}$

Their awareness can be traced to a number of factors-people's greater concerns with their material interests as their living standard improves and their wealth accumulate, greater media coverage over people's legal rights, and the state's recent efforts to protect citizens' social and economic rights through constitutional amendment, such as that protects their private property. In addition, it is likely that citizens are increasingly aware of the "best practice" regarding state protection of citizens' rights and citizens' initiatives in defending their rights in more developed economies, including Hong Kong, which is adjacent to Guangdong Province, as well as Taiwan, South Korea, Japan, and the West. This change suggests rising Chinese consciousness as citizens, a slow maturation of the Chinese society and its growing embrace of international norms for citizens' rights.

The Chinese are more willing to turn to legal action, complaints and protests in order to safeguard their rights. This change in public consciousness of the law and legal rights can be found in results of surveys over the years. One 1999 survey of 1,460 residents in four cities suggested that in addressing disputes with state authorities, 67 percent of urban residents chose appeals to high level state authorities, 44 percent contacting the media, and 30 percent resort to the law. A nationwide survey in 2005

\footnotetext{
${ }^{3}$ See Wang Guiyu, “An Empirical Study on the Chinese Citizens' Constitutional Awareness" (zhuanxing shiqi Zhongguo gongmin xianzheng yishi de shizheng yanjiu), posted at http://article.chinalawinfo.com, accessed on 20 March 2009.
} 
suggested that the percentage of urban residents willing to use law to resolve their disputes with the state went up to 51 percent, that of those who would approached leaders of the agency in dispute and leaders at upper-level leaders declined to 15 and 18 percent, respectively, and that of those who intended to approach the media dropped to 6 percent. ${ }^{4}$ The Chinese growing awareness of their rights and legal assertiveness are also reflected in the growing number of cases for re-trial in China in the recent years. A senior judge at the Chinese Supreme Court attributed it to the growing Chinese consciousness of their legal rights, their unhappiness with improper legal procedure in the first trial and their resort to retrial for justice. ${ }^{5}$

Meanwhile, the Chinese are less willing to trust the state authorities or the media in their recourse. They are also more willing to act in a group in order to enhance their bargaining power vis-à-vis the state and protect each individual in the process. As a result, the percentage of the Chinese petitioners in person grew from 60 percent in 1998 to 76 percent in 2001. The aforementioned national survey in 2005 indicated that 13 percent of the Chinese did use collective petition to solve their disputes with the state. ${ }^{6}$

The growing rights and legal consciousness apparently suggests that the Chinese society is maturing, although slowly. The Chinese citizens are becoming conscious of their legitimate rights as citizens, increasingly reluctant to place their hope for defense of their rights on state authorities and officials, and increasingly willing to use the court, which is seen as less partial than other state branches, to resolve their disputes with the state, and assert their independence from the state. This trend indicates Chinese citizens' (especially urban Chinese) growing awareness of utility of the legal system. It also demonstrated an alarming decline in citizens' trust in the state authorities, local leaders, and the media. This dwindling trust in state authorities, as we shall see, has a grave implication for social stability in China.

\section{Fast Economic Opening and Positive Side of Governance}

As stated earlier, China's model of development is characterized by fast social and economic opening but slow political opening. One of the defining feature (or component) of China's model of development is its model of governance. There are two sides of the same "coin" of the Chinese governance. On the one hand, the Chinese state is very effective in opening up the economy, building a market economy, and generating economic growth. On the other hand and as to be elaborated in the coming section, the Chinese state has been slow and ineffectual in protecting the citizens' social and economic rights, in easing popular grievances, and in enforcing rule of law. These two conflicting sides of the coin make up for what I can pro-growth authoritarianism.

The positive side of the Chinese governance helps to explain why the Chinese state has been very effective in opening up the economy, mobilizing resources, reforming its inefficient economic system, and paving the way for high economic growth.

\footnotetext{
${ }^{4}$ See Yongshun Cai, "Social Conflicts and Modes of Action in China," The China Journal, No. 59, January 2008: 106, 102.

5 “Gong Ming: Increase in Retrial Cases Reflect Growing Citizens' Consciousness with Rigths," (Gong Ming: Zaishen anjian shuliang zengzhang fangying le gongmin quanli yishi zengqiang), 2008-03-14 11:16:48, posted at http://www.chinacourt.org on 14 March 2008.

${ }^{6}$ Cai, "Social Conflicts and Modes of Action in China," 102-3.
} 
Specifically, the Chinese state outperforms many other developing countries in the following two important areas.

First, dramatic economic opening and promotion of trade (especially exports). Economic opening is regarded as a key to success in East Asia including China. ${ }^{7}$ China has been one of the few developing nations that has made rapid and decisive stride toward opening up its economy. Within less than three decades, China has transformed itself from one of the most isolated economies to an economy closely integrated with the world economy. China's promotion of exports that confirm to China's comparative advantage helps transformed the economy into a powerhouse of exports and a major manufacturing base.

From the 1960s to the late 1970s China pursued self reliance and isolated itself from the market-oriented world economy. Between 1955 and 1978, China was nearly free of foreign direct investment (FDI). During this period, tensions created a rift in China's relations with the United States and with the USSR after 1960, thereby preventing mass introduction of investment from the Eastern and Western countries and the USSR. Foreign loans, a politically less sensitive form of foreign capital, played a minor role in development, especially between 1960 and 1976.

Since the late 1970s, with the firm support from initially Deng Xiaoping and later his successors, China decisively opens up its closed economy and steadily integrates with the world market. There have been several landmark developments. First, in 1979 four special economic zones (SEZs) were approved. Second, in 1984, fourteen coastal port cities which accounted for 23 percent of the nation's industrial output, including Tianjin, Shanghai, Dalian, Qingdao, Ningbo, Wenzhou and Guangzhou, were opened up. Then from 1985 to 1988 major coastal economic areas were also opened up. From 1992 onwards in the wake of Deng's reform-promoting tour, inland border cities and provincial capitals were opened up. In 2001, China took a historical step in its opening. It joined the World Trade Organization, subjecting itself to the rules governing international trade, and linking itself closely with the world economy. ${ }^{8}$ China agreed to reduce average tariff levels for agricultural products to 15 percent and for industrial products to 8.9 percent by 2004. China also agreed to open significant service markets such as tele-communications, banking, insurance, securities, audiovisual, professional services, and importantly, wholesale and retail trade, post-sale service, repair, maintenance, and transportation. ${ }^{9}$ Finally, in the reform era China also actively promotes its exports and attracts foreign direct investment (FDI). One primary measure, as described above, is incremental and steady opening of localities and economic sectors and fiscal incentives for foreign investors.

China's promotion of exports helps transformed the economy into a powerhouse of exports and a major manufacturing base. China's exports grew from $\$ 18.2$ billion in 1980 to $\$ 968.9$ billion in 2006 , and China's FDI grew from $\$ 1.96$ billion in 1985 to $\$ 69.5$

\footnotetext{
${ }^{7}$ Shujie Yao, Economic Growth, Income Distribution and Poverty Reduction in China under Economic Reforms (Oxon and New York: RoutledgeCurzon, 2005), 84-99; Jeffrey Sachs, The End of Poverty: How We Can Make It Happen in Our Lifetime (London and New York: Penguin Books, 2005), 264.

${ }^{8}$ For a discussion on the topic, refer to Hongyi Lai, Reform and the Non-state Economy in China: The Political Economy of Liberalization Strategy. New York and Houndmills: Palgrave Macmillan, 2006, 45-59.

${ }^{9}$ Nicholas Lardy, Integrating China into the Global Economy. Washington, DC: Brookings Institution Press, 2002, 65-66.
} 
billion in 2006, a 34.5 folds increase. ${ }^{10}$ In 2003, China's FDI inflows reached $\$ 53,505$ million, the largest in the developing world. It was five times as much as that of Brazil $\left(\$ 10,144\right.$ million) and 12 times that of India $\left(\$ 4,269\right.$ million). ${ }^{11}$ China quickly surpassed other developing nations to become a major exporter of manufactures. By 2004 the share of manufactured goods in China's exports reached 91 percent, similar to that of South Korea (93 percent). It far surpassed that of India (77 percent), Vietnam (50 percent), Indonesia and Brazil (52 percent), and Egypt (31 percent). ${ }^{12}$

In 2007 China's external market size, measured by exports of goods and services, was ranked No. 1 worldwide, even ahead of the U.S., Germany and Japan. In 2004, China's exports amounted to $\$ 593,369$ million. It was six times that of Brazil $(\$ 96,474$ million), eight times that of India (\$72,530 million) and Indonesia (\$69,710 million). ${ }^{13}$

Second, capacity to undertake reform and development. The Chinese state is capable of undertaking major tasks during reform and development. For example, it overcame conservative opposition and successfully spread the household farming and economic opening nationwide. It has made noticeable progress in reforming its restriction of non-state business and inefficient SOEs. Since the early 1980s the Chinese government has also identified areas (such as counties) of poverty and introduced economic and social programs to lift the population there out of poverty.

One of the most important factors underlying the effectiveness of the Chinese state is that it has a relatively able leadership and bureaucracy. The Chinese leaders in the reform era, Deng in particular, possessed adroit political skills in overcoming and negotiating through obstacles and opposition and pushing through reform policies. For example, he pushed hard for reform and opening when the opportunities were ripe (from 1978-1980 and from 1984-87) or critical (such as in 1992). He retreated temporarily when reform was dealt with setbacks, such as 1989-91. In addition, he strategically selected localities that had the greatest local popular and official support and best geoeconomic conditions to experiment with reform and opening. He also appointed able leaders to lead those localities. They included Guangdong in the 1980s and 1990s and Shanghai after the mid 1980s. He also allowed these localities to retain a higher share of fiscal income during their experimental reform. Success of these provinces stimulated reform efforts and demands for liberalization from other provinces. ${ }^{14}$ Under the reformist leadership, the bureaucracy and the Party apparatus have been transformed from ones that were suited to political control and ideological indoctrination to one that maintains stability, encourages rapid economic growth and delivers decent macro economic management. For example, two key measures that the Chinese leaders such as Deng Xiaoping adopted was to promote younger officials with knowledge in economic

\footnotetext{
${ }^{10}$ National Statistical Bureau of China (NSB), China Statistical Yearbook 2006, Beijing: China Statistical Press, 2006, "Table 18-5--Exports Value by Category of Commodities" and "Table 18-14- Utilization of Foreign Capital".

${ }^{11}$ World Bank, World Development Report 2006, Washington, D.C.: World Bank, 298-299.

${ }^{12}$ Betina Dimaranan, Elena Ianchovichina and Will Martin, "Competing with Giants", L. Alan Winters and Shahid Yusuf, eds. Dancing With Giants: China, India, and the Global Economy (Singapore: The World Bank and Institute of Policy Studies, 2007), 73-74.

${ }^{13}$ Klaus Schwab and Michael E. Porter, The Global Competitiveness Report 2008-2009 (Geneva: World Economic Forum, 2008), 384.

${ }^{14}$ For an in-depth analyses of China's reform strategies, refer to Lai, Reform and the Non-state Economy in China, Chapters 3, 5, 6, and 7 (61-90; 109-190).
} 
management and who had successfully generated rapid economic growth in the units or localities under their jurisdiction. This practice helped transform Chinese officials from ideological indoctrinators into official entrepreneurs. ${ }^{15}$

In global comparison, the Chinese bureaucracy is relatively efficient in processing business cases and welcoming foreign investment. According to The Global Competitiveness Report 2008-2009 it took 35 days in China days required to start a business in 2007, much better than Vietnam (50), Indonesia (105), and Brazil (152). It lagged slightly behind India (33 days) and Nigeria (33 days). In terms of rules favoring foreign direct investment, China was ranked No. 55 out of 134 economies, behind Vietnam (No. 38), slightly behind that U.S. (No. 53). China was ahead of India (No. 61), France (No. 65), and Thailand (No. 68), and well ahead of Brazil (No. 82). ${ }^{16}$

Some scholars, like Bruce Gilley, questioned that the Chinese authoritarian state helped to drive China's high economic growth. ${ }^{17}$ Nevertheless, as the aforementioned analysis and literature indicate, authoritarianism did play a positive role in the Chinese miracle. Ogden's view which Gilley criticized thus made sense. She faulted Indian government for failing to solve social problems and credited the Chinese state for carrying out policies in the long-term interest of the population. ${ }^{18}$ As far as quickly lifting the population out of poverty is concerned, the Chinese state has been more effective than the Indian state. From 1981 to 2001 the percentage of the population in poverty declined by about $40 \%$ in China, doubling that in India in the same period. ${ }^{19}$

Overall, thanks to the aforementioned strengths of the Chinese governance China enjoys the highest economic growth for the past three decades in the world. China's GDP per capita at exchange rate increased from US\$227 in 1978 to US\$2,485 in 2007. China's economic performance even dwarfs that of India, which has attracted international attention for its starlet growth performance. From 1995 to 2004 China's annual GDP growth reached 9.1 percent, 3.1 percent higher than that of India. ${ }^{20}$

\section{Slow Opening of Politics and Limits of Governance}

Despite the aforementioned advantages, the limits of China's model of governance are also apparent. They are reflected in a host of serious problems, including weak rule or law and official corruption, violations of citizens' rights by the powerful and the rich, unequal distribution of the fruits of high growth, as well as environmental degradation.

\footnotetext{
${ }^{15}$ For studies on the topic, refer to Lai, Reform and the Non-state Economy in China, Chapters 4 and 9 (91108; 236-41); Lance Gore, Market Communism: The Institutional Foundation of China 's Post-Mao HyperGrowth (Hong Kong: Oxford University Press, 1998); Susan Whiting, Power and Wealth in Rural China: The Political Economy of Institutional Change (New York: Cambridge University Press, 2001).

${ }^{16}$ Klaus Schwab and Michael E. Porter, The Global Competitiveness Report 2008-2009 (Geneva: World Economic Forum, 2008), 428, 433.

${ }^{17}$ Bruce Gilley, 2005. "Two Passages to Modernity," in Edward Friedman and Bruce Gilley, eds. Asia's Giants: Comparing China and India (New York and Houndmills, Palgrave Macmillan), 19-54.

${ }^{18}$ See Suzanne Ogden, 2002. Inklings of Democracy in China (Cambridge, MA: Harvard University Asia Center), pp. 369, 371.

${ }^{19}$ Jeffrey Sachs, The End of Poverty: How We Can Make It Happen in Our Lifetime (London and New York: Penguin Books, 2005), pp. 154, 182.

${ }^{20}$ L. Alan Winters and Shahid Yusuf, eds. 2007. Dancing With Giants: China, India, and the Global Economy. Singapore: The World Bank and Institute of Policy Studies, Table 1.1.
} 
As a result, the rich and the powerful tend to benefit more from reform and development than do the lower class.

In many ways, the positive and negative sides of China's pro-growth governance are intricately interrelated. A single-minded pursuit of high growth and refusal to open up the political system are interlocked core features of pro-growth authoritarianism. In 1979, in response to the Democracy Wall Movement in Beijing, Deng spelled out the "four cardinal principles". The most important principle was to uphold the CCP's leadership of the nation. The "four cardinal principles" were cemented as the political pillar of the Party in the following decade, with the purges of two liberally-minded Party's General Secretary, i.e., Hu Yaobang in 1987 and Zhao Ziyang in 1989 and with the rise of orthodox reformists led by Deng, who embraced rapid economic opening and reform but slow political opening. ${ }^{21}$

Growth-oriented authoritarianism is based on all-out efforts to promote high growth for the Party's continued dominance. Deng, as well as his successors who I coin orthodox reformists, believed that the Party could sustain its political power through promoting economic growth and improving people's material well-being. ${ }^{22}$ Simply put, until the recent years, there has been a prevalent thinking among China's leaders and officials that high economic growth and a living standard are sufficient to earn the Party political legitimacy. ${ }^{23}$

In actual policy making and implementation officials perceive that respects for citizens' social and economic rights, economic justice, and environmental protection would increase considerably difficulties for materializing high growth within a short span and would even slow down economic growth. As the Party dominates politics and can implement policies without political opposition and with little social resistance, officials are able and in fact tend to push forth their pro-growth agenda without taking into account people's legitimate concerns. Meanwhile, free from public supervision and monopolizing political power, officials were tempted to trade their control of market entry and economic resources for wealth from the rich or the gangsters. This gave rise to corruption and criminal gangs. Nevertheless, violations of citizens' rights, unequal distribution of wealth, and limited channels for public grievances inevitably lead to mass popular protests. In the following paragraphs major problems in governance will be discussed briefly.

\section{Lack of Rule of Law and Rampant Corruption}

China's top leaders started to actively and publicly promote rule of law back in the late 1990s. At the closing ceremony of the annual session of the NPC in March 1996, Qiao Shi, the chief of the Chinese legislature (National People's Congress), formally called on the Party to "rule the country in accordance with law, and build a legally institutionalized

\footnotetext{
${ }^{21}$ For an analysis of leadership conflict over political opening and of rise of orthodox reformists, refer to Lai, Reform and the Non-state Economy in China, Chapter 3 (pp. 61-90).

${ }^{22}$ For an analysis of orthodox reformists headed by Deng, refer to Lai, Reform and the Non-state Economy in China, Chapter 3 (pp. 61-90).

${ }^{23}$ For a discussion and a critique of the Party's approach to legitimacy, refer to Lynn White, "Introduction: Dimensions of Legitimacy," in Lynn White, ed. Legitimacy. Singapore: World Scientific, 2005, 3-4; Yongnian Zheng and Liangfook Lye, "Political Legitimacy in Reform China," ibid, 186-96; Zhengxu Wang, "Political Trust in China: Forms and Causes," ibid, 128-38; 118, 121.
} 
socialist country." One month after his assumption of the post of the Party's General Secretary, Hu Jintao declared at a meeting of at the $20^{\text {th }}$ anniversary of implementation of the Constitution of the People's Republic of China that Party should abide by the Constitution. $^{24}$ Nevertheless, in reality, the courts at all levels are dominated by a political and legal committee of the Party at the same level and the courts are hardly independent in reaching verdicts. ${ }^{25}$ The courts and judges cannot independently make legal decisions and are subject to political interference.

In international perspective China's performance in rule of law is mediocre and falls well short of its economic competitiveness. Judicial independence is a key indicator of rule of law. In this aspect, China was ranked No. 69 out of 134 economies worldwide, It is far behind Egypt (No. 42) and India (No. 43) and very similar to Brazil (No. 68). This contrasts sharply with China's status as the No. 30 most competitive economy.

Concentration of power into the hands of a few leading Party officials at each level, their important role in economic decisions, as well as the rapidly expanding economy, create ample opportunities for the officials to enrich themselves. On the other hand, institutional and public restraints on official behavior are ineffectual due to the lack of genuine rule of law, opening of the political process, lack of public supervision, and the absence of an independent press. Very often, several top local leaders, especially the Party Secretary, control key personnel appointments, ${ }^{26}$ including the members of the political and legal committee and the head of the Department of Propaganda, and even top managers of leading local newspapers and TV stations (which are usually state owned). They thus indirectly dictate local legal decisions. No local courts and local media dare to challenge the decisions and policies formulated by local leaders. Nor will they take up cases or stories suggesting of corruption of these leaders. This usually gives a green light for abuse of power and corruption of local leaders.

In addition, as guanxi plays a key role in official promotion, candidates for office may resort to bribery and nepotism in order to gain office. Furthermore, officials whose career advancement is less promising may also concentrate on rent-seeking activities, instead of polishing their performance records in order to advance their careers. These traits of official behavior only induce corruption. ${ }^{27}$

Transparency International, a reputed international agency, ranked China No. 78 out of 159 countries and areas in the world in 2005. Mainland China earned a meager 3.2 out of a scale of 10, as 10 stood for no corruption. Its low score was in sharp contrast with other high-scoring Asian economies_-Singapore's 9.4, Hong Kong's 8.3, Japan's 7.3, Taiwan's 5.9, and South Korea's 5.0. It also lagged behind several other developing Asian economies-Malaysia (5.1), Thailand (3.8), and even very backward Laos (3.3). It was also behind several major emerging economies such as Brazil (3.7) and Poland (3.4).

\footnotetext{
${ }^{24}$ Hongyi Lai, Hu Wen quan toushi: Hu Wen shizheng neimu quan jiedu ji Zhongguo weilai zhanwang (HuWen under Full Scrutiny: A Comprehensive Inside Story of Governance under Hu and Wen and Prospects for Future China) (Hong Kong: Wenhua yishu chubanshe, 2005, pp. 75-79.

${ }^{25}$ Minxin Pei, China's Trapped Transition: The Limits of Developmental Autocracy (Cambridge, MA and London, 2006), 69-72.

${ }^{26}$ Yang Zhong, Local Government and Politics in China: Challenges from Below (Armonk, NY: M.E. Sharpe, 2003), pp. 105-109.

${ }^{27}$ Ibid, pp. 109-126.
} 
The only comforting fact was that China was slightly ahead of other slightly poorer Asian economies, i.e., India (2.9), Vietnam (2.6), Philippines (2.5), and Indonesia (2.2). ${ }^{28}$

The severity of corruption in China was also confirmed by a survey from late 2006 to early 2007 among private entrepreneurs in coastal China who had a more intimate knowledge about official rent-seeking behavior. Some 19.0 percent of the respondents agreed with the statement that most officials in their county or city were corrupt and 63.1 percent agreed that some officials in their county or city were corrupt. ${ }^{29}$ Official rent-seeking and corruption is thought to be more serious in inland areas. Therefore, overall corruption in China remains serious.

\section{Unequal Distribution of Wealth}

In the reform era, under Deng's call, some areas, especially the coastal region, were encouraged to grow earlier and faster than the rest of the nations and certain social groups, especially entrepreneurs and managers, to get rich first. This uneven growth policy was to break Mao's egalitarianism that discouraged individual entrepreneurship, productive activities, and innovations. As a result, income inequalities in China have grown. The Gini coefficient of income distribution in China registered a low 0.288 in 1981, yet soared to an alarming 0.403 in 1998; it continued to rise 0.459 in 2001, on par with US's $0.466 .{ }^{30}$ China's Gini coefficient further rose to 0.496 in 2005 . In 2006 in a nationwide public opinion survey income inequalities were regarded the third most serious social problems. $^{31}$ Income inequalities developed along three dimensions-rural-urban gap, inter-regional gap (most noticeably coastal-inland gap), and inter-strata gap. Nevertheless, weak state institutions for income redistribution do not help to stem the income gaps. As a result, inequalities along these three dimensions continue to grow. Out of the three dimensions the most alarming is rural-urban income gap. The disposable income of an average peasant was equivalent to 53.8 percent of that of an average urban resident in 1985 . It declined sharply to 34.9 percent in 1994 and registered a deplorable 30.5 percent in $2006 .^{33}$

Until recent years the state, especially at the local level, has tried much hard in catering to the needs of entrepreneurs than offering economic assistance and provisioning welfare to the lower classes. Social spending out of governmental budget is viewed as

\footnotetext{
${ }^{28}$ Transparency International Secretariat, Transparency International Corruption Perceptions Index 2005, Berlin, 2005, posted at http://www.transparency.org.

${ }^{29}$ Jie Chen and Bruce J. Dickson, "Allies of the State: Democratic Support and Regime Support among China's Private Entrepreneurs," China Quarterly, 196, December 2008, p. 17.

${ }^{30}$ Hongyi Lai, "Growth with Rising Income Inequality: China's Response to the Problem," EAI Background Brief No. 227 (Singapore: East Asian Institute, February 16, 2005). This is a recent discussion and survey of the issue.

${ }^{31}$ Li Peilin, Chen Guangjin and Li Wei, "A Report on a Survey on the Conditions of Social Harmony and Stability in China in 2006," Ru Xin, Lu Xueyi, and Li Peilin. eds. 2007 nian: Zhongguo shehui xingshi fenxi yu yuce (Analyses and Forecasts on China's Social Development). Beijing: Shehui Kexue Wenxian Chubanshe, 2007, pp. 24-5.

${ }^{32}$ See World Bank, Sharing Rising Incomes (Washington, D.C.: World Bank, 1997), p. 7. For studies on income inequality in China, refer to Riskin, Carl, Zhao Renwei, and Li Shi. eds. China's Retreat from Equality, Income Distribution and Economic Transition (Armonk, NY: M E Sharpe, 2001).

${ }^{33}$ My own computation using data from National Bureau of Statistics, China Statistical Yearbook 2007 (Beijing: China Statistical Press, 2007), Table 10-2.
} 
economically wasteful and unhelpful for generating high economic growth. Many officials would rather concentrate on wooing investment in order to generate GDP than on collecting and channeling revenue into the financing of local welfare programs and for equal income distribution.

\section{Violation of Citizens' Rights in Development}

Many officials view high growth as the ultimate barometer of governance of their localities. They often regard local residents' legitimate demand for protection of their interests obstacles to the rapid economic development. For example, they favor swift confiscation of rural land for industrial parks and estate development and make low compensation for peasants in order to reduce business costs and woo investors. In addition, they treat local people's complaints about infringement of their social-economic interests (such as resettlement, pollution and noise from plants) by local developmental projects as trouble making and detrimental to their pursuit of high growth. They rely on public security or even mafia to suppress protestors.

One of the most serious and widespread cases of infringement of rights arise from the use of agricultural land. It was estimated that from 1987 to 2001 34-51 million peasants lost their land to non-agricultural use of land. According to a survey of ten provinces, 69 percent of the land of industrial park was taken over by local authorities illegally. In many of these cases, inadequate compensation was quite common. In particular, in inland provinces such as Henan, Yunnan, Shanxi, peasants' income declined by 25,26 , and 9.4, percent, respectively. Even in coastal provinces such as Tianjin and Liaoning, despite higher income after compensation, peasants who lost land suffered from a real decline in income due to their moving into urban areas where living expenses were higher. There were cases where village cadres enriched themselves whereas villagers received only a portion of compensation that was deemed reasonable. These cases of official corruption in land use served to instigate social tensions and conflict. ${ }^{34}$

\section{Limited Channels for Remedies of Public Grievances}

From the beginning of reform, China's leaders rejected any conspicuous attempt to open up the political system and introduce democracy. The only exception is direct and relatively open election of village chiefs and villager committees. ${ }^{35}$ As a result of this political strategy, China has indeed avoided the political upheavals and instability that the former Soviet Union (such as Russia and its former Republics in Central Asia), as well as democratized Asian nations such as Indonesia, the Philippines and Thailand experienced.

However, the development-first strategy has entailed grave political, social and even economic consequences. The ruling Chinese Communist Party has maintained the

\footnotetext{
${ }^{34}$ Li Xiaoyun, Tang Lixia, and Zhang Keyuan, "Conditions of Land-losing Peasants from 2003-2004," in Li Xiaoyun, Zuo Ting, and Ye Jingzhong, eds. 2003-2004 Zhongguo nongcun qingkuang baogao (A Report on the Conditions of China's Countryside), Beijing: Shehui Kexue Wenxian Chubanshe, 2004, 287-304.

${ }^{35}$ For a discussion on rural election, refer to Yang Zhong and Jie Chen, "To Vote or Note to Vote: An Analysis of Peasant Participation in Chinese Village Elections," Comparative Political Analysis 35: 6 (2002), 686-712; Tianjian Shi, "Voting and Nonvoting in China: Voting Behavior in Plebiscitary and Limited Choice Elections," The Journal of Politics 61: 4 (November 1999), 1115-39; Kent M. Jennings, "Political Participation in the Chinese Countryside," American Political Science Review 91 (1997), 361-72.
} 
closed political system. There have been few channels for the public and concerned parties to influence and shape public policy. As Bernstein and Lü observed in their study on protests in rural China, peasants protested, sometimes even violently, because local officials arbitrarily imposed economic burdens on them through illicit taxation, fees and projects and targeting meeting without consulting peasants. ${ }^{36}$

As a result of the closed political system and largely closed policy making process, policies that are implemented can be short-sighted and do little to improve people's wellbeing. In addition, new officials may pursue a whole set of policies different from their predecessors in order to claim political credits. Officials have weak incentives to help out disadvantaged groups. These groups include rural migrants and the poor, as well as a portion of the Tibetan and Uighur population. These groups benefit modestly from economic development. These groups inevitably feel that they lag far behind other groups in the course of rapid economic development and are neglected by the government.

Pro-growth authoritarianism that has been discussed inevitably leads to social grievances. As their legitimate rights are violated urban residents and rural residents try to seek justice. ${ }^{37}$ One form of action is individual or collective appeals to officials. Nevertheless, the citizens' channels for complaints and grievance airing are restricted due to the institutional barriers the state has set up. As Cai put it, "workers and peasants have experienced significant failures using appeals in their struggles against abusive cadres". 38

Most importantly, the institutional setup largely discourages officials from responding promptly and effectively to citizens' complaints. Officials are appointed by their superiors; getting along with colleagues and other officials is thus important for leaving a good impression upon the superiors. Addressing infringement of legitimate economic and social rights by the officials and the rich would require decisive action that may risk alienating colleagues, subordinates and local powerful groups and may invite their retributions. Without effective institutions of public supervision and censor such as free elections of officials and a free press, local officials and courts are under no public pressure to address public grievances. Some local officials even call upon the police and gangsters to prevent disgruntled people from airing their grievances to their superiors. In response, discontented citizens resort to disrupting public order and destroying public property and governmental offices in order to vent their grievances and anger. Their rationale may be that by escalating the tension protesters they would attract the higher authority's attention to their grievances and that the higher authority will then force the local official to change their behavior.

\section{High Growth Coupled with Frequent Protests in China}

China has maintained rapid economic growth during the past three decades. From 1978 to 2008 China's GDP grew at a brisk 9.8 percent per annum, and increased by fifteen folds.

\footnotetext{
${ }^{36}$ Thomas Bernstein and Xiaobo Lü, Taxation without Representation in Contemporary Rural China (Cambridge and New York: Cambridge University Press, 2003), pp. 12-15, 250-51.

${ }^{37}$ For a study on rural protests, see Kevin O'brien and Lianjiang Li, Rightful Resistance in Rural China (Cambridge and New York: Cambridge University Press, 2006).

${ }^{38}$ Yongshun Cai, "Managed Participation in China," Political Science Quarterly, Vol. 119, No. 3, $2004: 444$.
} 
From 1993 to 2006, China's GDP annual growth rate ranged from 7.6 percent to 14 percent. The average growth at nearly 10 percent (9.96 percent to be exact) was higher than the averaged growth rate of 9.6 percent from 1978-92. ${ }^{39}$ One may be tempted to conclude that thanks to higher economic growth China should witness fewer popular protests in the later period than the earlier period.

However, what actually happened was the opposite. From 1993 to 2005, China witnessed a steady and rapid growth in collective grievances and protests. The number of petitions to the national government, a key Chinese form of expressing grievances especially at the local levels, was only 297,900 in 1984 . But it started to grow in the 1994 and totaled 586,400 in 2000 and reached 603,000 in $2005 .^{40}$

China's GDP grew on average at 9.8 percent a year from 1994-1999 and 9.5 percent from 2000-2006. As the economic performance in these two periods was very impressive and comparable, popular protests in these two periods should have been stable in number and small in total. In China a more direct and explosive form of expression of public grievances is collective protests, which refer to protests by over five participants. The number of collective protests registered at 10,000 in 1994; it increased to 32,000 in 1999. Instead of declining during the period of 2000-2006, it creased further to 40,000 in 2000 and grew steadily to an estimate 90,000 in 2006. ${ }^{41}$ The period of 2000-2006 witnessed more frequent collective protests than that of 1993-99. In 2006 the number of collective protests was 10.3 times of that in 1993, averaging nearly 20 percent growth per annum, more than twice as fast the GDP growth rate.

Thus it is apparent that high economic growth does not necessarily lead to solid political legitimacy of the ruling elites, nor does it preempt popular dissatisfaction with the political regime. Even though high economic growth may increase the level of popular support for the regime, it does not preclude outbreaks of popular protests. Indeed, this is the hardest lesson the CCP learned in the summer of 1989 and from 1993 to 2006. The following is an analysis of one of the most-noticed riots in China in 2008, which can help shed light on the negative implications of uneven opening in China in the economy, society and politics for social stability and the society, as well as pro-growth authoritarianism. It also suggests the Chinese leaders' awareness of societal opening and their more pragmatic approach to social protests.

\section{Weng'an: Protests against Erroneous Pro-Growth Governance}

Among the recent protests in the 2000s few may match the scale of the riots in Weng'an in June 2008. The riots in Weng'an illustrate well the side effects of blatant pursuit of high economic growth at the expenses of people's social and economic rights, as well as the dark side of pro-growth governance in China. They also shed light on the dynamics of interaction between discontented people, predatory officials, and the usually far-away

\footnotetext{
${ }^{39}$ China Statistical Yearbook, 2006, 2007.

${ }^{40}$ Yongshun Cai, "Social Conflicts and Modes of Action in China," The China Journal, No. 59, January 2008, 97.

${ }^{41}$ For data on protests from 1993 to 2006, refer to Jae Ho Chung, Hongyi Lai and Ming Xia, "Mounting Challenges to Governance in China: Surveying Collective Protestors, Religious Sects, and Criminal Organizations," China Journal, July 2006, No. 56: 6; Xu Xunlei, “The First Step toward Collective Incidents Should Be to Desensitize Them" (dui qunti shijian diyibu yao zuodao "tuomin"), posted at http://blog.zjol.com.cn/, accessed on December 20, 2008.
} 
central government. As the riots in Weng'an became a national and international news headline, top leaders of China were so alarmed at the appalling errors in governance of Weng'an that they immediately acted to address the popular grievances there.

\section{The Trigger and the Riots}

Weng'an is a county in Guizhou, one of the least developed provinces in China. On June 21, 2008, Li Shufen, nearly 16-year-old junior high school female student, committed suicide by jumping into a river at night. Liu, a friend of Li's boyfriend Chen, tried to rescue her but failed. All three went to the riverside after a drinking session. Miss Wang, Li's classmate, who was also at the scene, stated that Li had long resented her parents' prejudiced treatment of her as a girl and that this could be a cause for her death. ${ }^{42}$ Later rumors spread in the county that Li was raped by Chen and Liu, murdered and thrown into the river, that Chen and Liu were relatives of local ranking officials and that the local police covered up the case and protected them. For days parents of Li refused to accept the official verdict that $\mathrm{Li}$ committed suicide and placed the body of their daughter at the scene of the incident. Rumors also were circulated in the county that Li's uncle, aunts, grandparents and mother was beaten by the local security.

On the afternoon of June 28, 300 people gathered near Li's body and marched to the office of the county's public security. By 4 pm nearly 10,000 people assembled outside the office. The confrontation between police and protesters, however, went out of control. At 4:30 pm protesters and spectators started to break into the office building, smashed and burned offices, and broke into offices of the nearby people's government, the bureau of finance, and the Party committee of the county. By 6 pm the crowd reached 20,000. Police vehicles were set on fire. A crowd of about 10,000 remained outside the governmental office buildings until 3 a.m. of June 29 . On the early next morning a crowd of about 6,000 gathered again and tried to break into governmental offices. They were dispersed by the armed police. The rioters destroyed much of office buildings for the county's Party committee, people's government (the administration) and public security, as well as 42 cars; 150 people were injured. ${ }^{43}$

\section{Sources of Protests}

In fact, in the recent years the economy of the county has been growing rapidly thanks to a number of economic initiatives. However, the controversial death of Li directly triggered the mass riots in the county. According to emerging official in-depth investigations, the real sources of tensions laid in the erratic governance of the county. Shi Zongyuan, Guizhou's Party Secretary, pointed out three main causes of the riots. The first two were particularly relevant for my argument here. The first cause was that interests of Weng'an residents were violated in the extraction of minerals and resettlement and that local leaders often used public security forces to suppress people's grievances. The second cause was that that the county's leaders and public security failed

\footnotetext{
42 "Three Eye Witnesses in the Death of Li Shufen Restored the Original Scene," posted at http://bbs.phoer.net, accessed on January 30, 2009.

43 "The Beginning and the End of the Weng'an Incident and the Provincial Party Secretary Apologized to the Common People Three Times," Xinhua, July 5, 2008.
} 
to crack down on local crime and criminal gangs, that many local crimes remained unsolved and that local people lost their trust in the public security. ${ }^{44}$

Several cases show vividly how the local government's reckless pursuit of high growth and blatant transgression of people's rights sowed the seeds for unrest. One case was the extraction of the phosphorus ores, one of the rich minerals in the county, in the Yan'gen Village. Back in 1998 Weng'an County Phsphorization Company started to extract minerals underneath the village. By 2003, the operation caused a drop in the water level in the Tianba Group of the village. As a result, the paddy field of $285 \mathrm{mu}$ could not irrigated, the spring villagers used as drinking water source was polluted, and the livelihood of 280 villagers was threatened. The villagers appealed to the township government in vain. In January 2007 the county granted the rights to Aisikai Company to extract ores in the village, and a provincial commercial newspaper estimated the output of the extraction would worth 200 million yuan. Villagers made collective appeals to local government and demanded that the issues about drinking water, paddy irrigation and sinking of the ground be addressed before the start of the extraction. Villager representatives even travelled to Guiyang, the provincial capital. But again, there was no solution to their satisfaction. In March villagers blocked the entry of representatives from the township and county governments. In April the county government summoned villager representatives to the county office to discuss the resolution of the dispute. However, seven representatives were arrested upon arrival for criminal charges. Upon learning the news over 100 villagers went to the county office and entered into a row with the police. In December 2007 the seven villager representatives were sentenced by the county court to prison terms of two to seven years for disrupting public order, for causing losses of 2 million yuan in the operation of the Aisikai Company. Their appeal was overturned by the prefectural court.

The second case had to do with ran-away crimes, especially against teenagers. Crimes in the county ran out of control. Since 2006 several crimes victimizing teenagers had occurred in the county. In 2006 a nine -year old boy was kidnapped by human smugglers. When his uncle reported the case to the public security, he got into a quarrel with the police and was beaten up. In December 2007 a girl student was raped and murdered 200 meters outside her home, and the culprit remained at large. In addition, there were over ten known criminal gangs that rampaged in the county. They included the Jade Mountain Gang, the Ax Gang, and the Kitchen Knife Gang. Local residents refrained from going out after $7 \mathrm{pm}$ out of fear of robbery. As many crimes remained unsolved, local residents were greatly dissatisfied with the local security. Their distrust played a role in the spread of rumors about police cover-up of the rape and murder of $\mathrm{Li}$ and the outbreak of riots. ${ }^{45}$

\section{Aftermaths}

The mass riots in Weng'an shook the nation and the world. $\mathrm{Hu}$ Jintao, the Chinese President and the General Secretary of the CCP, urged quick and proper management of the protests. He also subtly blamed local authority for not resolving popular grievances in the past and for too readily using the police to suppress angry citizens. In the wake of

\footnotetext{
${ }^{44}$ Ibid.

45 “Weng'an Before the June 28 Incident," Liaowang Dongfang Weekly, No. 29, July 2008.
} 
the protests, the Party secretary, the magistrate, and the chief of public security of the Weng'an County were dismissed. Official media subtly portrayed these incompetent officials as a primary cause of the mass riots. Immediately after the riots, the Guizhou Provincial Party Secretary spent days in the county investigating the causes of the riots. One of the conclusions he draw was that the riots invalidated one of the theories once popular among Chinese officials that once the economy grew rapidly the society would be stable. ${ }^{46}$ The moderate and restrained response from the Chinese national and provincial leadership suggested that even the leadership was aware of the growing openness of the society and the need for changing the management of state-societal relations. However and unfortunately, this change does not apply to the political system as a whole.

In retrospect, the people in Weng'an claimed a moral victory by taking dramatic action. They exposed the long-existing problems in mis-governance of the locality and gained the much-needed attention to the embedded problems from the top leaders. In addition, they gained a far fairer treatment in the aftermath of the riots than most previous riots. In the past the state authority would have blacked out news reports and would have sent in the military, which would result in losses of lives in the conflict. It would have arrested the protest leaders, would have sentenced them to heavy terms if not death sentence, and would have condemned the riots as "anti-revolutionary" or "subversion of the state".

\section{Conclusion}

In the reform period China's economy and to a lesser extent society has undergone considerable opening. In contrast, much of the political process and political system remain closed, despite much progress compared to Mao's era. This article investigates the uneven opening of China's economy, society and politics as well as positive and negative sides of China's pro-growth governance. It suggests that the Chinese society has benefited from the opening and that the Chinese have become conscious of their legitimate social and economic rights and are willing to defend them. It also points out that the Chinese state has been very capable of rapidly opening up the economy, overcoming obstacles to economic development, and achieving growth.

The negative aspects of China's pro-growth governance, however, cannot be ignored. Negative byproducts of pro-growth authoritarianism include weak rule of law, official corruption, violation of people's rights, and few channels for public inputs in policy and public grievances. These defects of the Chinese governance help to account for outbursts of frequent protests during the period of high economic growth.

As China's economy rapidly expands and the Chinese living standard rises, the Chinese society is changing, becoming increasingly mature and open. As discussed above, the Chinese citizens are increasingly aware of their legal rights and have learned to forge social bonds within small groups for their own protection. They must also be aware of the good practice of rights protection and citizens' action in defending their rights in developed economies.

\footnotetext{
46 "The Beginning and the End of the Weng'an Incident and the Provincial Party Secretary Apologized to the Common People Three Times," Xinhua, July 5, 2008.
} 
For these reasons in the reform era high economic growth goes hand in hand in a rise in popular protests in China. In the 1980s democracy protests were the norm; into the 1990s and 2000s social protests have become daily occurrence. The case of Weng'an illustrates that high economic growth at the great expenses of people's legitimate demands for economic survival and public security will incite social protests, instead of generating popular support. Therefore, the argument which has been long accepted by the Chinese officials and even leaders that high economic growth would automatically translate into popular support and social stability is flawed.

On the other hand, the moderate state responses to riots in the recent months, such as those in Weng'an, indicate a growing strength of the Chinese society. Importantly, it points to national leaders' growing understanding of the increased opening of the society, social tensions, and their improvement in handling of social conflicts.

The seemingly viable way for China to escape the quandary of rising instability amidst high economic growth is to reform its pro-growth authoritarianism. A number of modifications of the tight authoritarian governance are vital for reduction of public discontent. An effective remedy of the sources of public grievances requires the opening of the political process for public participation, political transparency, media supervision, direct and public election of representatives, and greater independence of the legal system. Specifically, greater public inputs in economic policy making is needed, fair compensation for material losses in the execution of developmental projects is necessary, public yearning for a low-crime and economic security has to be satisfied, and public supervision and election of official policies needs to be implemented. Furthermore, media's open and truthful reports on political event and supervision of officials should be tolerated, and the court should be allowed to play a bigger role in resolving disputes, including those involving the state and citizens. Only by addressing the negative side of China's governance can China experience genuine social stability in the course of high growth. Otherwise, a state effective in pushing forth economic opening and generating growth but ineffective in protecting rights will continue to be harassed by social protests. 